\title{
Distribution, sedimentation and fate of pigment biomarkers following thermal stratification in the western Alboran Sea
}

\author{
R. G. Barlow ${ }^{1, *}$, R. F. C. Mantoura ${ }^{1}$ R. D. Peinert ${ }^{2}$, A. E. J. Miller ${ }^{1}$, T. W. Fileman ${ }^{1}$ \\ ${ }^{1}$ Plymouth Marine Laboratory, Prospect Place, West Hoe, Plymouth PL1 3DH, United Kingdom \\ ${ }^{2}$ Institut für Meereskunde, Düsternbrooker Weg 20, D-24105 Kiel, Germany
}

\begin{abstract}
A spring investigation of the phytoplankton in the western Alboran Sea (Mediterranean) was undertaken using chlorophyll and carotenoid biomarkers to characterize the community in the water column and in drifting sediment traps set at 100 and $200 \mathrm{~m}$. During 2 drifter experiments, calm and sunny conditions induced a progressive thermal stratification that reduced pigment sedimentation into deeper water and confined the phytoplankton to the surface layer, resulting in an increase in chlorophyll biomass. 19'-Hexanoyloxyfucoxanthin (prymnesiophytes) and chlorophyll $b$ (chlorophytes, prasinophytes, prochlorophytes) were the major accessory pigments, while fucoxanthin, alloxanthin and peridinin indicated the presence of diatoms, cryptophytes and dinoflagellates, respectively. The proportional contribution of each algal group to the chlorophyll a (chl a) biomass, as derived from multiple regression analysis, revealed that prymnesiophytes, cryptophytes and the green algal group collectively accounted for at least $75 \%$ in the upper $100 \mathrm{~m}$, emphasizing the importance of the nanophytoplankton. Phaeopigments, dominated by phaeophorbide $a_{2}$, were the main pigments observed in sediment traps, although chl $a$, fucoxanthin and 19'-hexanoyloxyfucoxanthin were detected in smaller concentrations as well as traces of chlorophyll $b$ (chl $b$ ). In deep water, fucoxanthin and $19^{\prime}$-hexanoyloxyfucoxanthin were the only accessory pigments present while total phaeopigment/chl a molar ratios $>1$ reflected the active transformation of fine phytogenic material at depth. High particulate organic carbon (POC)/chl $a$ ratios ( $>100$ in surface water; $>1000$ in deep water) suggested that phytoplankton was a relatively small component of the total carbon biomass down the water column. Using simple budget calculations, we determined that 58 to $65 \%$ of the chl a produced in the upper $100 \mathrm{~m}$ accumulated in the water column over both experiments. During Expt 1, 29\% of the chl a sedimented out, mostly as phaeopigment, at $100 \mathrm{~m}$ $(24 \%)$, and $6 \%$ was degraded to colourless residues in the water column. In contrast, only $12 \%$ of the chl a sedimented in Expt 2, while $20 \%$ was degraded to colourless residues.
\end{abstract}

KEY WORDS: Pigment biomarkers · Distribution · Sedimentation · Alboran Sea

\section{INTRODUCTION}

Investigations of the water masses in the western Alboran Sea have revealed the existence of an anticyclonic gyre that is formed by a jet of Atlantic surface water entering through the Straits of Gibraltar (La Violette 1984, Gascard \& Richez 1985). This Atlantic water is enriched with nutrients by an injection of North Atlantic Central Water in the Gulf of Cadiz and by tidal mixing with deeper outflowing Mediterranean water

•E-mail; r.barlow@pml.ac.uk in the straits (Minas et al. 1984, Packard et al. 1988). The enriched water curves along the Spanish coast as part of the gyre, supplementing the nutrient supply of upwelled waters on this coast which in turn enhances primary production (Packard et al. 1988, Minas et al. 1991). As a result, chl a levels of up to $3 \mu \mathrm{g} \mathrm{l}^{-1}$ have been measured in these upwelled waters along the northern sector of the gyre (Minas et al. 1991). Organic matter produced by these mechanisms is then distributed both by the anticyclonic flow of the gyre and by the water that converges at the centre. Sedimentation in the convergence zone delivers organic matter to 
deeper water, stimulating bacterial activity and the development of a pronounced oxygen minimum (Packard et al. 1988). The western Alboran Sea is therefore an area of intensive physical and biological interaction between Atlantic and Mediterranean water masses

These physical forcings directly affect the abundance and composition of the phytoplankton biomass in the gyre, but only a few studies have been conducted on the microalgal community in this area (Claustre et al. 1994a, b). Within the framework of the EROS-2000 programme, we participated in a research cruise to the western Alboran Sea in spring 1992 to study the distribution and vertical fluxes of the phytoplankton using chlorophyll and carotenoid pigments as biomarkers of the various algal classes, and to assess the transformation of $\mathrm{chl} a$ in the water column by means of phaeopigment tracers. On previous cruises, we have used a similar approach to investigate microalgal abundance and degradation in the northwestern Mediterranean (Mantoura et al. 1990) and the northeastern Atlantic (Barlow et al. 1993a, b). For 1 to $2 \mathrm{wk}$ prior to the cruise, storms and gale force winds in the Alboran Sea resulted in deep mixing of the upper $80 \mathrm{~m}$ followed by calm and sunny conditions during the cruise. In order to investigate the response of the phytoplankton to the stabilising environment, we followed the movement of the surface water mass in the southern sector of the western Alboran gyre by means of drifting sediment traps, and a series of measurements were made to characterise the particulate matter in the water column and in the traps. This paper presents the results of these experiments and we interpret the data in the context of thermally induced stratification.

\section{MATERIALS AND METHODS}

The cruise track, daily sampling stations, and the deployment and retrieval positions of 2 drifting sediment trap experiments are illustrated in Fig. 1. Two automated sediment traps (Technicap PPS 5, $1 \mathrm{~m}^{2}$ collection area), attached to a drifter, were set at 100 and $200 \mathrm{~m}$ depths (Peinert et al. 1993). Drifter 1 (5-8 March) headed south after deployment and was retrieved near the Xauen Bank off Morocco. Drifter 2 (8-11 March) was deployed a few nautical miles to the north and it drifted with the motion of the anticyclonic gyre until final recovery (position D, Fig. 1). Trap samples were collected at $24 \mathrm{~h}$ intervals and preserved in situ with $2 \%$ formaldehyde. Following recovery of the traps, subsamples were withdrawn, filtered, frozen and analysed on board as described below. A smaller dual cone trap $\left(0.08 \mathrm{~m}^{2}\right.$ collection area) was also deployed daily at $100 \mathrm{~m}$ to test the effects of preservative on pigment destruction; one collection cup contained $2 \%$ formaldehyde while the other was preservative-free.

Hydrographic measurements along the drifter trajectories were performed between $12: 00$ and $14: 30 \mathrm{~h}$ each day with a CTD profiler equipped with a 12-bottle rosette sampler. Samples (2 1) from 12 depths in the upper $200 \mathrm{~m}$ were filtered onto $25 \mathrm{~mm}$ GF/F filters, stored in liquid nitrogen, and analysed either on board or at the Plymouth Marine Laboratory. Further samples from 16 depths between 20 and $1200 \mathrm{~m}$ were also taken with the aid of Challenger Oceanic in situ stand alone filtration pumps (SAP) on 6 and 7 March. For deep samples, large volumes of water need to be filtered to obtain sufficient material for analysis and these pumps are capable of filtering up to $3000 \mathrm{l}$ of water at depths as deep as $5000 \mathrm{~m}$. Particulate material was collected on $293 \mathrm{~mm}$ GF/F filters and subsamples drawn for pigment and particulate organic carbon (POC) analysis, stored frozen as above. Deep CTD hydrographic profiles were also undertaken down to $1200 \mathrm{~m}$. POC analysis of decarbonated SAP samples were performed on a Carlo Erba elemental analyser using a modification of the method of Verardo et al. (1990).

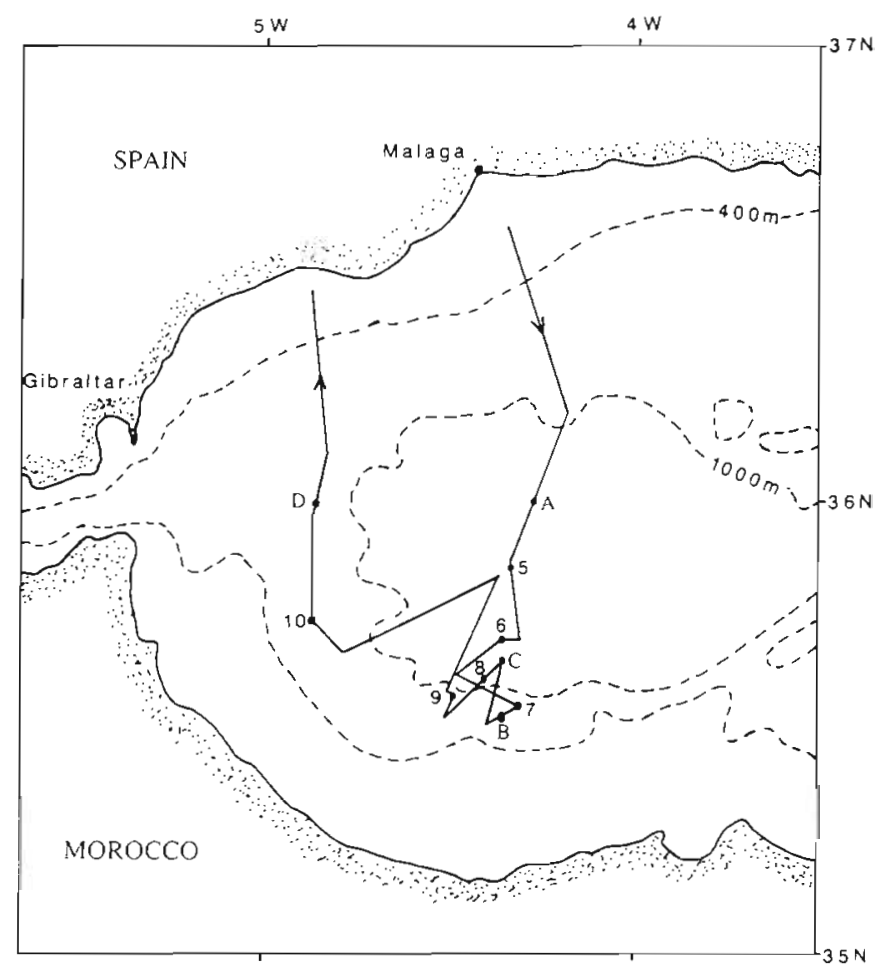

Fig. 1. Cruise track and daily sampling stations (5 to 10 March 1992) in the western Alboran Sea. Drifting trap 1 was deployed at position $\mathrm{A}$ and recovered at $\mathrm{B}$, while Drifter 2 was deployed at position $C$ and recovered at $D$ 
For pigment analysis, frozen filters were extracted in $90 \%$ acetone using sonication, centrifuged to clarify the extract, and the chlorophylls and carotenoids separated and quantified by reversed-phase HPLC according to Barlow et al. (1993a). In summary, extracts were mixed $(1: 1$, $\mathrm{v} / \mathrm{v}$ ) with $1 \mathrm{M}$ ammonium acetate and injected into a Shimadzu HPLC system incorporating a C-18 $3 \mu \mathrm{m}$ Pecosphere column $(3.3 \times 0.45 \mathrm{~cm}$, Perkin-Elmer $)$. A binary linear gradient was used to separate the pigments and solvent $A$ consisted of 80:20 (v/v) methanol:1 $M$ ammonium acetate, while solvent $B$ contained 60:40 (v/v) methanol:acetone. Chlorophylls and carotenoids were detected by absorbance at $440 \mathrm{~nm}$ and phaeopigment detection utilized fluorescence (Perkin-Elmer LS1) set at $400( \pm 20) \mathrm{nm}$ excitation and $>600 \mathrm{~nm}$ emission.

Pigments were identified by comparison with retention times of pigments isolated from the following well-documented microalgal species in the Plymouth Culture Collection (PCC): Thalassiosira weissflogii (PCC 541), Amphidinium carterae ( $\mathrm{PCC} 127$ ), Dunaliella tertiolecta (PCC 83), Imantonia rotunda (PCC 1779b), Synechococcus elongatus (PCC 543), Chroomonas salina (PCC 544). Peak identity was further confirmed on selected samples by on-line diode array visible spectroscopy (Waters 990) and quantitation of pigments has been described by Barlow et al. (1993a). Chlorophylls $a$ and $b$ (chl $a$ and $b$ ) were calibrated using authentic standards (Sigma Chemical Co.) in acetone and quantified spectrophotometrically using the extinction coefficients of Jeffrey \& Humphrey (1975). We employed the method presented by Barlow et al. (1993b) for estimating phaeopigment concentrations using extracts from mussel faeces of known phaeopigment composition.

\section{RESULTS}

An example of an absorbance chromatogram is presented in Fig. 2 showing the elution pattern of a range of chlorophyll and carotenoid pigments detected in the western Alboran Sea. Our method does not separate chls $c_{1}$ from $c_{2}$, nor lutein from zeaxanthin and we could not positively identify the presence of violaxanthin (in chlorophytes) and prasinoxanthin (in prasinophytes). Furthermore, the chl $a$ and $b$ concentrations reported here include possible contributions by divinyl chls $a$ and $b$ which are found exclusively in prochloro- phyte phytoplankton (Goericke \& Repeta 1992, Partensky et al. 1993) and are not separated from chls a and $b$. We selected 6 pigments as chemotaxonomic markers of the major algal classes and these included chl a as an indicator of phytoplankton biomass, peridinin (dinoflagellates), fucoxanthin (diatoms), 19'hexanoyloxyfucoxanthin (prymnesiophytes), alloxanthin (cryptophytes) and chl b (chlorophytes and prasinophytes). A diode array absorbance spectrum of peak 9 (Fig. 2, $\lambda=448,476 \mathrm{~nm}$ ) indicated that this peak was a mixture of zeaxanthin $(\lambda=452,478 \mathrm{~nm})$ and lutein $(\lambda=445,473 \mathrm{~nm})$ and generally their combined concentration was low $\left(<60 \mathrm{ng} \mathrm{l^{-1 }}\right.$ ). Lutein is present in chlorophytes, while zeaxanthin is a component of cyanobacterial cells such as Synechococcus sp. (Wright et al. 1991), but is also found in prochlorophyte algae (Goericke \& Repeta 1992). In a concurrent flow cytometric study of picoplankton on samples drawn simultaneously with our pigment samples, Vaulot \& Marie (1993) found very low concentrations of prochlorophytes but significant cell concentrations of picoeukaryotes $(<3 \mu \mathrm{m})$ that they suggested were prymnesiophytes and prasinophytes. The prasinophytes may have contained high levels of chl $b$, but low levels of prasinoxanthin which we could not detect, and therefore the chl $b$ reported here could be a signature for chlorophytes plus prasinophytes, with a minor contribution from prochlorophytes. In addition to the above pigments, the chlorophyll transformation products, phaeophorbide $a_{1}$, phaeophorbide $a_{2}$, phaeophytin $a_{1}$ 


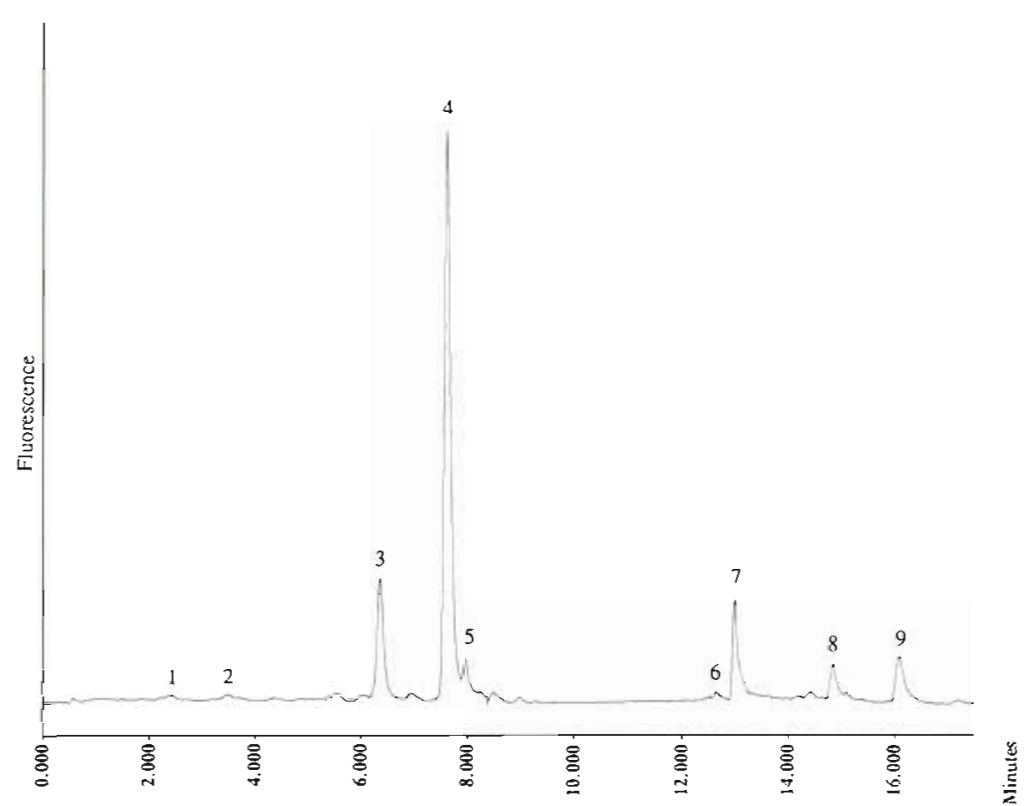

Fig. 3. HPLC fluorescence chromatogram of a $100 \mathrm{~m}$ trap sample collected over 6 and 7 March. Pigment identities are: (1) chlorophyllide $a_{1}(2)$ chl $c_{1} c_{2}$, (3) phaeophorbide $a_{1}$, (4) phaeophorbide $a_{2}$, (5) unknown, (6) chl a allomer, (7) chl a, (8) phaeophytin $a_{1}$, (9) phaeophytin $a_{2}$

and phaeophytin $a_{2}$ (Barlow et al. 1993b) were detected in low concentrations $\left(<50 \mathrm{ng} \mathrm{l}^{-1}\right)$ in the water column

Higher concentrations of these phaeopigments were detected in sediment trap samples (Fig. 3) with phaeophorbide $a_{2}$ (pyrophaeophorbide a, Barlow et al. 1993b) being the dominant chloropigment (up to $380 \mu \mathrm{g}$ per $250 \mathrm{ml}$ collection cup) and accounting for $80 \%$ by mole of the total phaeopigment concentration. Daily trap tests to check the response of pigments to $2 \%$ formaldehyde revealed no significant differences in pigment concentrations between preserved and nonpreserved samples over a $4 \mathrm{~d}$ collection period. We were unable to positively identify peak 5 in Fig. 3, but this pigment may have been a phaeoporphyrin c-like pigment as suggested by Head et al. (1994). Our phaeophorbide $a_{1}$ elution time was close to that of $19^{\prime}$ butanoyloxyfucoxanthin and therefore appears to be similar to the phaeophorbide a-like pigment reported by Head et al. (1994) to be a marker of dying phytoplankton during the late stages of a spring bloom. It is possible that our phaeophorbide $a_{1}$ was a marker of dying algae, but we have detected both phaeophorbide $a_{1}$ and $a_{2}$, and phaeophytin $a_{1}$ and $a_{2}$, during laboratory copepod and microzooplankton grazing experiments (unpubl. data) and so we are of the opinion that phaeophorbide $a_{1}$ is also a product of grazing activity (see Barlow et al. 1993b). The total phaeopigment levels reported in this paper are a summation of the concentrations of the phaeophorides and phaeophytins and used as a biomarker of chlorophyll transformation. Absorbance chromatograms of trap material were very complex and contained numerous peaks that appeared to be carotenoid transformation products. We positively identified chl a, chl a allomer, fucoxanthin, 19'-hexanoyloxyfucoxanthin and traces of chl $b$ in these chromatograms and did not attempt to identify any other peaks since we were primarily interested in the chlorophyll transformation products. Concentrations of the identified pigments ranged from 50 to $200 \mathrm{\mu g}$ per $250 \mathrm{ml}$ collection cup and the ratios of chl a plus allomer/fucoxanthin or 19'-hexanoyloxyfucoxanthin were 1.1 to 1.9 , suggesting that the accessory pigments in the traps were associated with chl $a$ and perhaps ungrazed cells.

The hydrographic features of the water column are shown in Fig. 4A, revealing a 3 layered structure. The upper 80 to $100 \mathrm{~m}$ layer of low salinity water $(<36.6 \mathrm{psu}$ ) had the characteristics of Atlantic water, while the high salinity water ( $>38.1$ psu) below $200 \mathrm{~m}$ is Mediterranean water (Minas et al. 1991). Between 100 and $200 \mathrm{~m}$ was a zone of intermediate salinity that appeared to be a mixture of Atlantic and Mediterranean waters. Temperature profiles were the opposite of salinity, with the upper $100 \mathrm{~m}$ being the warmest $\left(>14.8^{\circ} \mathrm{C}\right)$ and thereafter decreasing with depth such that the Mediterranean water below $200 \mathrm{~m}$ was $<13.4^{\circ} \mathrm{C}$ (Fig. 4A). The actual structure and circulation pattern in the Alboran Sea is more complex than our simple description, however, and Gascard \& Richez (1985) and Minas et al. (1991) present a more detailed understanding of these water masses. The daily temperature and sigma-t profiles in the top $200 \mathrm{~m}$ (Fig, 4, 5-10 March) indicated that the calm and sunny weather had a warming effect on the water column. Temperatures in the upper 80 to $100 \mathrm{~m}$ were $>14.8^{\circ} \mathrm{C}$ on all days and a notable feature was the increase in temperature in the surface $30 \mathrm{~m}$ layer. Sigma- $t$ values were $<27.35$ in the Atlantic water and in response to the warming the density of the water decreased at the surface (Fig. 4, 5-10 March). Overall, these observations suggested that a process of stabilization was occurring in the study region, although we could not establish that this was the case in one single water body due to patchiness and lateral advection (Peinert unpubl. data).

Vertical SAP profiles of selected pigments for 6/7 March are presented in Figs. 5 \& 6. Highest concentrations were measured in the upper Atlantic water, where chl a levels ranged from $688 \mathrm{ng} \mathrm{l}^{-1}$ at $20 \mathrm{~m}$ to $375 \mathrm{ng} \mathrm{l}^{-1}$ at $80 \mathrm{~m}$ and then decreased rapidly 

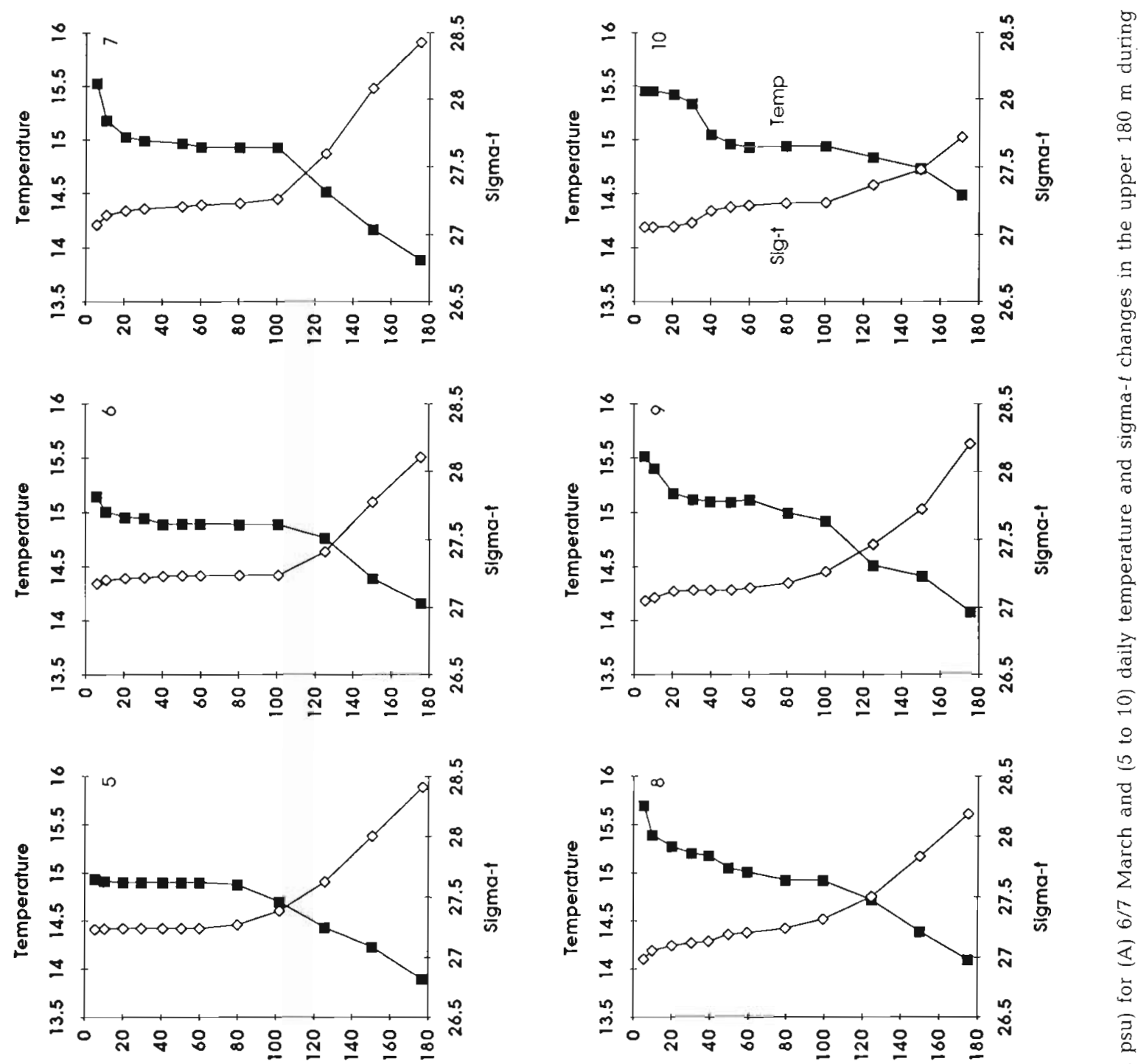

(w) पıdəo

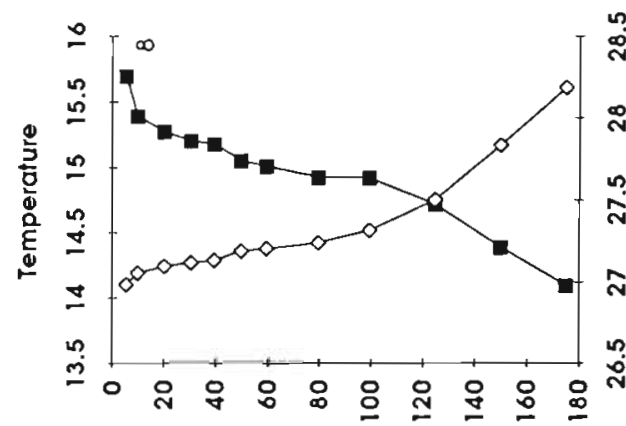

(ui) पाde0

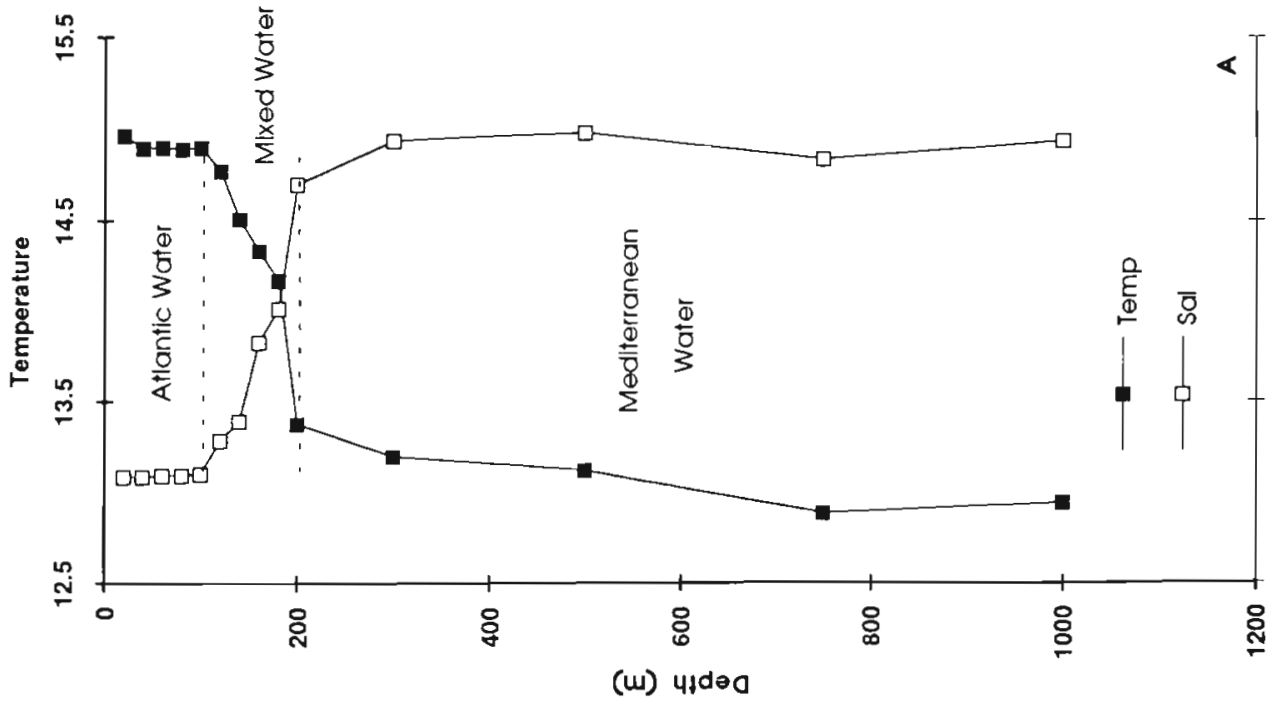



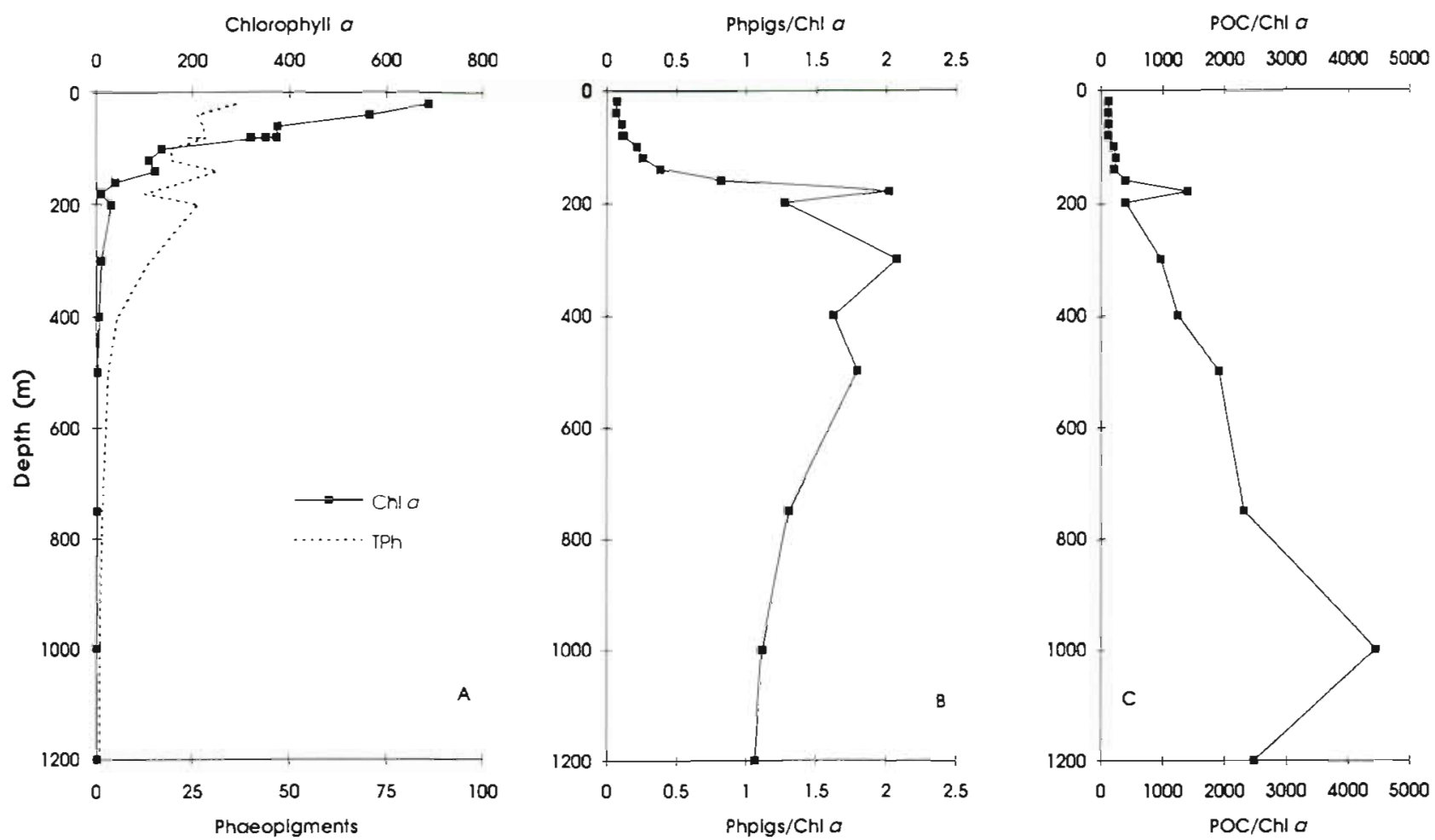

Fig. 5. Vertical distribution of (A) chl $a$ and total phaeopigment (TPh) concentrations (ng $\mathrm{l}^{-1}$ ), (B) the total phaeopigment/chl a molar ratio, and $(C)$ the particulate organic carbon/chl a weight ratio for $6 / 7$ March
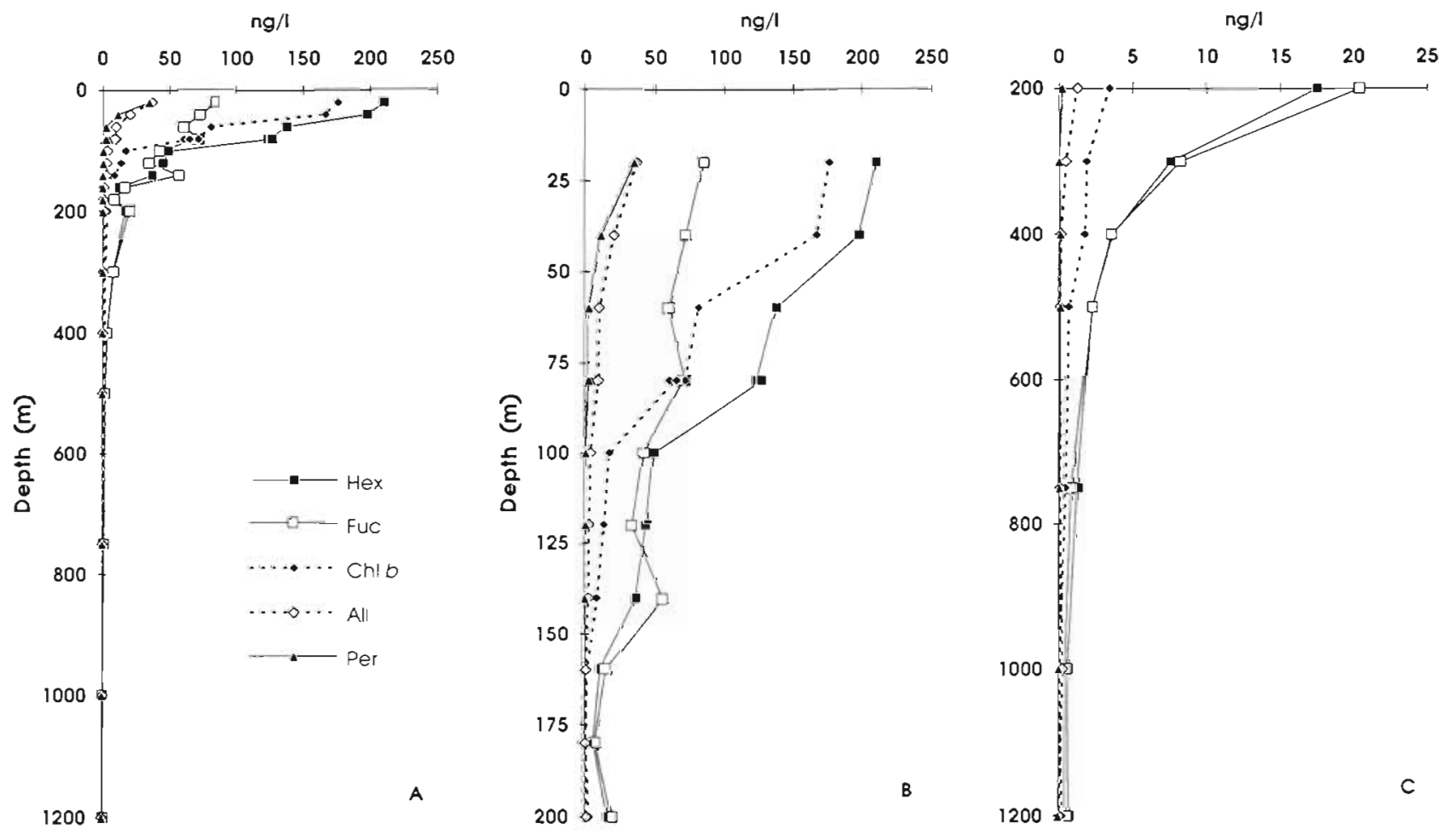

Fig. 6. Depth profiles of the concentrations of 5 selected pigments between (A) 20 and $1200 \mathrm{~m}$, (B) 20 and $200 \mathrm{~m}$, and (C) 200 and $1200 \mathrm{~m}$ for 6/7 March. Hex: 19'-hexanoyloxyfucoxanthin; Fuc: fucoxanthin; Chl $b$ : chlorophyll b; All: alloxanthin; Per: peridinin 
with depth to $1 \mathrm{ng} \mathrm{l}^{-1}$ at $1200 \mathrm{~m}$ (Fig. 5A). 19'-Hexanoyloxyfucoxanthin (127 to $211 \mathrm{ng} \mathrm{l}^{-1}$ ) and chl $b$ (65 to $176 \mathrm{ng} \mathrm{l}^{-1}$ ) were the dominant accessory pigments in the upper $80 \mathrm{~m}$ (Fig. 6A, B), followed by fucoxanthin (42 to $85 \mathrm{ng}^{-1}$ ), while alloxanthin and peridinin concentrations were considerably lower $\left(<50 \mathrm{ng} \mathrm{l}^{-1}\right)$. Concentrations of all these pigments decreased with depth to $<100 \mathrm{ng} \mathrm{l}^{-1}$ (Fig. 6A, B, C). Phaeophorbide $a_{2}$ accounted for $70 \%$ of the total molar phaeopigment concentration and total phaeopigment levels (13 to 35 ng $\mathrm{l}^{-1}$ ) were much lower than chl a concentrations in the top $160 \mathrm{~m}$ (Fig. 5A), although below this depth phaeopigment levels were greater than chl a. Consequently, the total phaeopigment/chl a molar ratios were very low $(0.1$ to 0.2$)$ in the upper $100 \mathrm{~m}$, increased to 2.0 to 2.1 at 180 to $300 \mathrm{~m}$, and then declined with depth to 1.1 at $1200 \mathrm{~m}$ (Fig. 5B). Carbon/chl a weight ratios averaged 120 in the top $100 \mathrm{~m}, 200$ to 400 between 100 and $200 \mathrm{~m}$, and increased with depth to 4500 at $1000 \mathrm{~m}$ (Fig. $5 \mathrm{C}$ ).

The response of the phytoplankton community to the stabilising conditions is shown in Figs. $7 \& 8$. On 5 and 6 March the chl a concentration in the surface layer was about $600 \mathrm{ng} \mathrm{l}^{-1}$ and by 7 March had increased to $900 \mathrm{ng} \mathrm{l}^{-1}$ at 20 to $30 \mathrm{~m}$ (Fig. 7). With increasing depth these levels decreased steadily to $100 \mathrm{ng} \mathrm{l}^{-1}$ or less at $175 \mathrm{~m}$. During the second drifter experiment, chl a concentrations were much greater in the upper 10 to $30 \mathrm{~m}$. ranging from 1200 to $1600 \mathrm{ng} \mathrm{l}^{-1}$ and then decreased rapidly with depth to $<100 \mathrm{ng} \mathrm{l}^{-1}$ (Fig. 7). Phaeopigments were dominated by phaeophorbide $a_{2}(54 \%$ at the surface and $70 \%$ below $20 \mathrm{~m}$ ) and their levels were very low relative to chl $a$, these being $<30 \mathrm{ng} \mathrm{l}^{-1}$ at all depths sampled except at 150 and $175 \mathrm{~m}$ on 5 March and at the surface on 10 March when $50 \mathrm{ng} \mathrm{l}^{-1}$ were recorded. Estimates of total phaeopigment/chl a molar ratios gave values $<0.1$ down to $100 \mathrm{~m}$, but between 100 and $175 \mathrm{~m}$ these ratios ranged from 0.15 to 0.65 , consistent with the SAP profiles.

Of the accessory pigments, $19^{\prime}$-hexanoyloxyfucoxanthin was generally dominant in the upper layers, although chl $b$ was also prominent (Fig. 8). At the pigment maximum, 19'-hexanoyloxyfucoxanthin concentrations were 200 to $250 \mathrm{ng} \mathrm{l}^{-1}$ during 5-7 March and 400 to $525 \mathrm{ng} \mathrm{l}^{-1}$ for $8-10$ March, while chl $b$ levels were $507 \mathrm{ng} \mathrm{l}^{-1}$ on 8 March. Fucoxanthin concentrations were lower than 19'-hexanoyloxyfucoxanthin and $\mathrm{chl} b$ down to $80 \mathrm{~m}$, but below this depth fucoxanthin was the most significant together with 19'hexanoyloxyfucoxanthin (Fig. 8). Levels of alloxanthin and peridinin were mostly $<50 \mathrm{ng} \mathrm{l^{-1 }}$ below $20 \mathrm{~m}$ but increased up to $100 \mathrm{ng} \mathrm{l}^{-1}$ in the surface $20 \mathrm{~m}$ layer on some days (Fig. 8). The interesting feature of these pigment profiles is the greater concentration in the upper $30 \mathrm{~m}$, coinciding with the warmer and less dense water in this surface layer
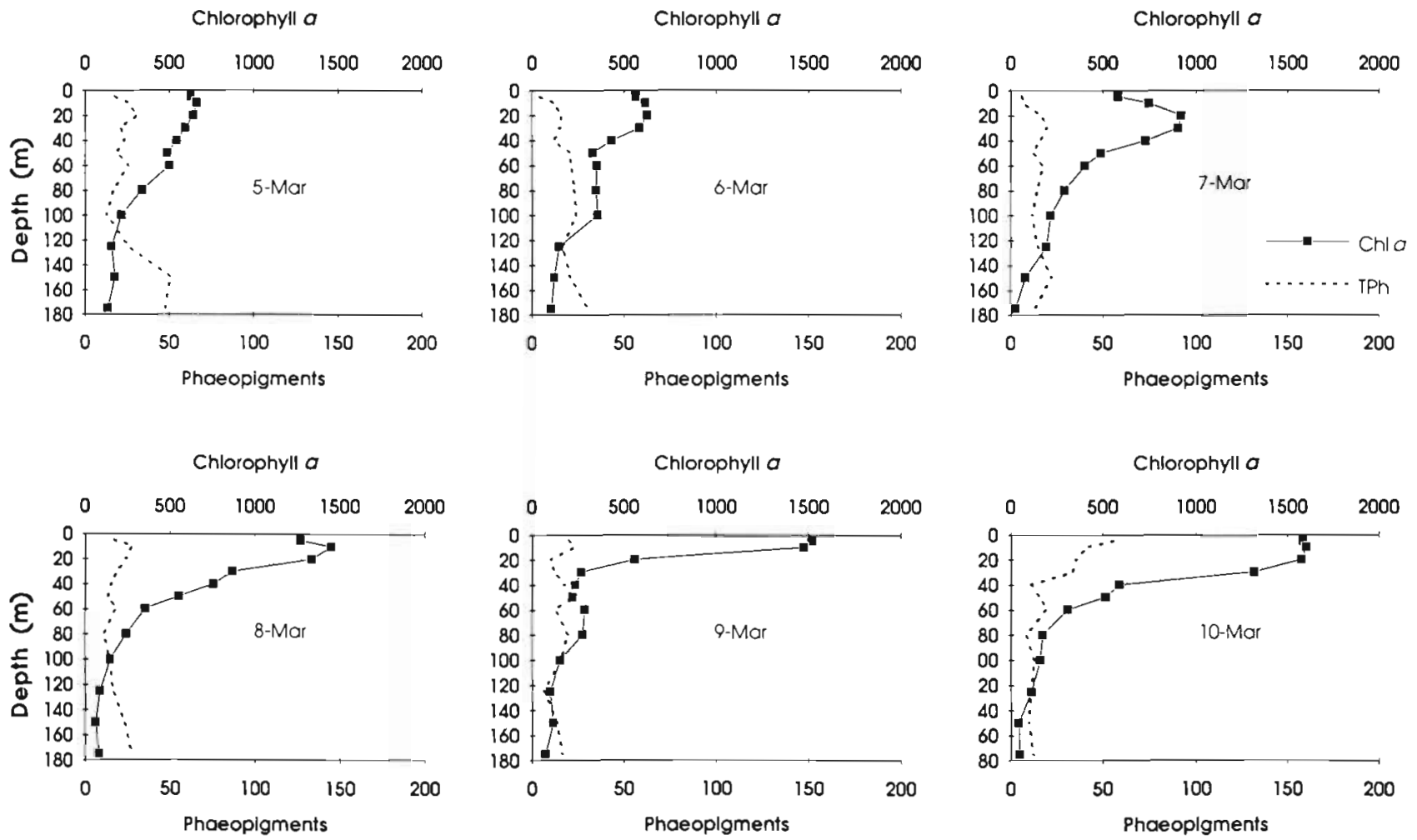

Fig. 7. Chlorophyll a and total phaeopigment (TPh) concentrations (ng $\mathrm{l}^{-1}$ ) in the top $180 \mathrm{~m}$ between 5 and $10 \mathrm{March}$ 

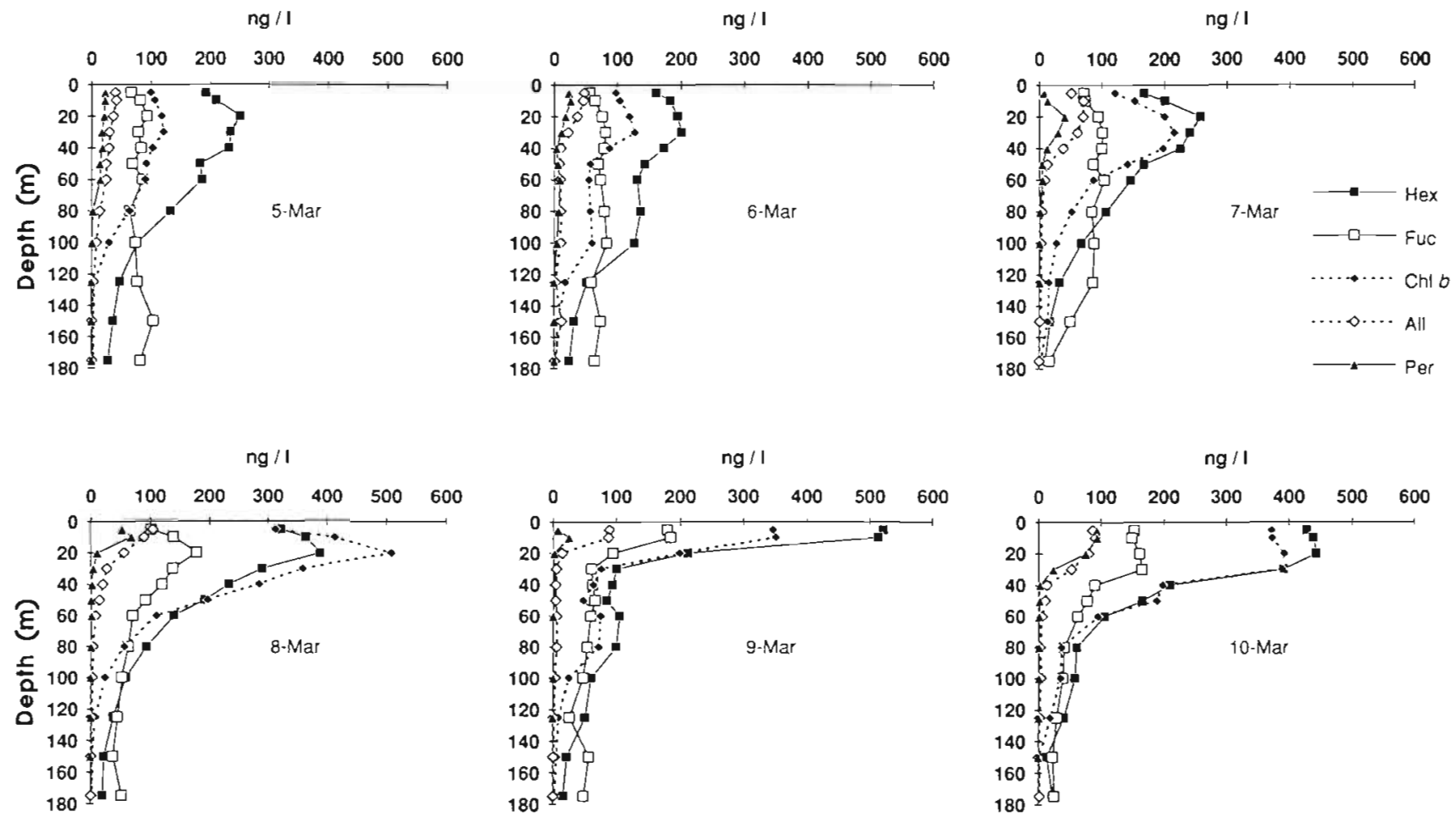

Fig. 8. Profiles of the concentrations of 5 selected pigments in the upper $180 \mathrm{~m}$ for 5 to 10 March. Hex: 19'-hexanoyloxyfucoxanthin; Fuc: fucoxanthin, Chl $b$ : chlorophyll $b$; All: alloxanthin; Per: peridinin

In order to assess the standing stock of the various pigments in the water column for comparison with vertical fluxes, integrated concentrations were estimated by the trapezoidal method over 0 to $100 \mathrm{~m}$ and 100 to $175 \mathrm{~m}$ (Table 1). The mean integrals in the upper $100 \mathrm{~m}$ for $\mathrm{chl}$ a were $25 \%$ greater during drifter Expt 2 com- pared to Expt 1 and the accessory pigment integrals were also slightly greater, although chl $b$ was approximately double during Expt 2. In the 100 to 175 m layer, integrated levels were lower in both experiments but the concentrations during Expt 1 were higher than Expt 2, especially for fucoxanthin. The mean inte-

Table 1. Depth-integrated pigment concentrations $\left(\mathrm{mg} \mathrm{m}^{-2}\right.$ ) along the trajectories of drifter Expt 1 ( 4 to 8 March) and drifter Expt 2 (8 to 11 March). Chl a: chlorophyll a; Fuc: fucoxanthin; Hex: 19'-hexanoyloxyfucoxanthin; Chl $b$ : chlorophyll $b$; Allo: alloxanthin; Per: peridinin; Phpig: total phaeopigments

\begin{tabular}{|c|c|c|c|c|c|c|c|c|}
\hline & \multicolumn{4}{|c|}{ Expt 1} & \multicolumn{4}{|c|}{ Expt 2} \\
\hline & $5 \mathrm{March}$ & 6 March & 7 March & Mean & 8 March & 9 March & $10 \mathrm{March}$ & Mean \\
\hline \multicolumn{9}{|c|}{$0-100 \mathrm{~m}$} \\
\hline Chl a & 48.89 & 44.43 & 54.48 & 49.27 & 67.22 & 46.53 & 73.66 & 62.47 \\
\hline Fuc & 7.71 & 7.56 & 9.09 & 8.12 & 10.00 & 8.12 & 9.45 & 9.19 \\
\hline Hex & 18.25 & 15.72 & 16.72 & 16.89 & 20.79 & 16.94 & 22.04 & 19.92 \\
\hline Chl $b$ & 8.80 & 8.02 & 12.25 & 9.69 & 22.01 & 11.97 & 19.84 & 17.94 \\
\hline Allo & 2.59 & 1.95 & 3.01 & 2.52 & 2.91 & 1.87 & 3.10 & 2.63 \\
\hline Per & 1.36 & 1.10 & 1.13 & 1.19 & 1.15 & 026 & 2.52 & 1.31 \\
\hline Phpig & 2.12 & 1.77 & 1.40 & 1.76 & 1.69 & 1.67 & 2.27 & 1.87 \\
\hline \multicolumn{9}{|c|}{$100-175 \mathrm{ml}$} \\
\hline Chl a & 12.82 & 12.48 & 9.87 & 11.72 & 6.57 & 8.02 & 6.52 & 7.04 \\
\hline Fuc & 6.48 & 5.20 & 4.72 & 5.47 & 3.45 & 3.31 & 2.14 & 2.97 \\
\hline Hex & 3.43 & 4.01 & 2.25 & 3.23 & 2.56 & 2.81 & 2.42 & 2.59 \\
\hline Chl $b$ & 0.62 & 1.40 & 1.10 & 1.04 & 0.63 & 0.72 & 1.02 & 0.79 \\
\hline Allo & 0.23 & 0.52 & 0.13 & 0.29 & 0.14 & 0.13 & 0.15 & 0.14 \\
\hline Per & 0.02 & 0.07 & 0.01 & 0.03 & 0.02 & 0.01 & 0.04 & 0.02 \\
\hline Phpig & 2.67 & 1.61 & 1.23 & 1.84 & 1.51 & 0.89 & 0.83 & 1.08 \\
\hline
\end{tabular}


Table 2. Vertical fluxes of pigment sedimentation $\left(\mathrm{mg} \mathrm{m}^{-2} \mathrm{~d}^{-1}\right)$ along the trajectories of drifter Expt 1 (4 to 8 March) and drifter Expt 2 ( 8 to 11 March). Chl a: chlorophyll $a_{\text {; }}$ Chl a-allo: chlorophyll a allomer; Fuc: fucoxanthin; Hex: 19'-hexanoyloxyfucoxanthin; Chl $b$ : chlorophyll $b$; Phpig: total phaeopigments

\begin{tabular}{|c|c|c|c|c|c|c|c|c|c|}
\hline & \multicolumn{5}{|c|}{ Expt 1} & \multicolumn{4}{|c|}{ Expt 2} \\
\hline & 4-5 March & 5-6 March & 6-7 March & 7-8 March & Mean & 8-9 March & $9-10 \mathrm{Mar}$ & $10-11 \mathrm{Mar}$ & Mean \\
\hline \multicolumn{10}{|l|}{$100 \mathrm{~m}$ flux } \\
\hline Chl a & 0.12 & 0.09 & 0.05 & 0.13 & 0.09 & 0.04 & 0.08 & 0.16 & 0.09 \\
\hline Chl a-allo & 0.22 & 0.12 & 0.06 & 0.15 & 0.14 & 0.03 & 0.04 & 0.08 & 0.05 \\
\hline Phpig & 0.71 & 0.73 & 0.34 & 0.69 & 0.62 & 0.14 & 0.28 & 0.51 & 0.31 \\
\hline Fuc & 0.17 & 0.14 & 0.08 & 0.17 & 0.14 & 0.04 & 0.06 & 0.12 & 0.07 \\
\hline Hex & 0.21 & 0.19 & 0.13 & 0.25 & 0.19 & 0.06 & 0.12 & 0.20 & 0.13 \\
\hline $\mathrm{Chl} b$ & 0.02 & 0.01 & 0.06 & 0.04 & 0.03 & 0.02 & 0.05 & 0.08 & 0.05 \\
\hline \multicolumn{10}{|l|}{$200 \mathrm{~m}$ flux } \\
\hline Chl a & 0.04 & 0.004 & 0.01 & 0.05 & 0.03 & 0.01 & 0.003 & 0.007 & 0.008 \\
\hline Chl a-allo & 0.06 & 0.005 & 0.01 & 0.02 & 0.02 & 0.007 & 0.001 & 0.002 & 0.004 \\
\hline Phpig & 0.27 & 0.07 & 0.16 & 0.27 & 0.20 & 0.06 & 0.01 & 0.02 & 0.03 \\
\hline Fuc & 0.02 & 0.01 & 0.03 & 0.05 & 0.03 & 0.01 & 0.004 & 0.007 & 0.008 \\
\hline Hex & 0.05 & 0.02 & 0.06 & 0.09 & 0.06 & 0.02 & 0.005 & 0.009 & 0.01 \\
\hline $\mathrm{Chl} b$ & 0.009 & 0.0004 & 0.001 & 0.02 & 0.007 & 0.005 & 0.001 & 0.002 & 0.003 \\
\hline
\end{tabular}

grated phaeopigment levels were very similar in both experiments in the top $100 \mathrm{~m}$, but 1.7 times greater between 100 and $175 \mathrm{~m}$ in Expt 1 compared to Expt 2 (Table 1).

Sedimentation rates of pigments collected in the traps are shown in Table 2 and the dominance of the phaeopigment flux complemented the microscopic analysis of Peinert et al. (1993) who reported that zooplankton faecal pellets of different sizes were the major constituents of trap material. Pigment sedimentation was considerably greater at 100 than $200 \mathrm{~m}$ (Table 2), consistent with the observation of higher standing stocks in the upper $100 \mathrm{~m}$ Atlantic water (Table 1). While sedimentation fluxes of $\mathrm{chl} a$ and $b$ at $100 \mathrm{~m}$ were similar in both experiments, the other pigments sedimented faster during Expt 1, particularly the phaeopigments whose flux was 3 to 5 times that of the other pigments.

\section{DISCUSSION}

\section{Pigment signatures}

The circulation of water masses in the western Alboran Sea raises interesting questions concerning the interaction of Atlantic and Mediterranean waters and the consequent composition and fate of the phytoplankton community in the region. In March 1992, we encountered a situation in which the water column was stabilizing after the abatement of stormy weather and under nutrient-sufficient conditions (e.g. nitrates ranged from 1.5 to $2.5 \mathrm{mmol} \mathrm{l}^{-1}$. Cruzado \& Martinez 1993) it appeared that we were investigating the early stages of a spring bloom. Our approach of using pig- ment biomarkers to distinguish various algal groups is similar to that adopted in other studies by Gieskes et al. (1988), Bidigare et al. (1990), Everitt et al. (1990), Ondrusek et al. (1991) and Barlow et al. (1993a) for example. The results presented here revealed that prymnesiophytes, and to certain extent chlorophytes and prasinophytes, dominated the phytoplankton in the upper Atlantic water, while diatoms together with prymnesiophytes were prominent deeper in the water column (Figs. 6 \& 8). These observations complement those of Lohrenz et al. (1988) and Claustre et al. (1994b) who report significance abundances of prymnesiophytes in the Algerian current and the western region of the Almeria-Oran front, respectively, to the east of our study area.

To assess the proportional contribution of the various phytoplankton groups to the chl a biomass using pigment signatures, it was necessary to determine the pigment ratio of each biomarker relative to chl a. We attempted this task using individual linear regressions of chl a against each pigment, but these gave very low estimates of the slope of the regression $(0.04$ to 0.28 ) and were deemed to be unrealistic as appropriate ratios (cf. Gieskes et al. 1988, Barlow et al. 1993b). Theoretically, each marker pigment is proportional to the different phytoplankton groups which contribute collectively to the chl a biomass. Multiple regresion analysis is therefore a more suitable method for examining the relationships between chl $a$ and the various accessory pigments, and the partial regression coefficients in the regression equation give an estimate of the ratio of chl a/accessory pigment. Such an approach has been applied successfully by Gieskes et al. (1988) and Barlow et al. (1993a) in previous pigment studies. 
A multiple regression analysis of the 6 selected biomarkers in the upper $200 \mathrm{~m}$ gave the following solution:

$$
\begin{aligned}
(\mathrm{chl} \mathrm{a})= & -17.784+1.135(\mathrm{Hex})+0.898(\mathrm{chl} \mathrm{b}) \\
& +1.337(\text { Fuc })+3.602(\text { Allo })+2.791(\text { Per })
\end{aligned}
$$

The $\mathrm{r}^{2}$ for this regression was 0.997 and the partial regression coefficients were significant at the $1 \%$ level with standard erorrs ranging from 0.06 to 0.26 . The intercept in this model gave a chl a value of $-17.784 \mathrm{ng}$ $1^{-1}$, which is effectively very small considering that most of the chl a values were 150 to $1600 \mathrm{ng} \mathrm{l}^{-1}$, and reflects the possible contribution of other minor groups. These contributors could have included chrysophytes (19'-butanoyloxyfucoxanthin), cyanobacteria (zeaxanthin) and prochlorophytes (divinyl chl a and zeaxanthin). We detected a mixture of zeaxanthin and lutein in low concentrations (see 'Results') and therefore estimated the contribution of cyanobacteria, and also prochlorophytes, from the data of Vaulot \& Marie (1993) (see below). We have not used 19'-butanoyloxyfucoxanthin as a biomarker since Barlow et al. (1993a) suggested that this pigment is not exclusive to chrysophytes and can be a component in certain prymnesiophyte cells.

We substituted the integrated pigment concentrations presented in Table 1 in the above equation to determine the overall contribution of each class to the biomass in the upper $100 \mathrm{~m}$ (Table 3). Prymnesiophytes were clearly the dominant class, accounting for 34 to $42 \%$ of the chlorophyll biomass in both experiments, while the contributions of diatoms (17 to $23 \%$ ), cryptophytes (15 to $20 \%$ ) and dinoflagellates (2 to $10 \%$ ) were slightly greater during Expt 1 , but only by 1 to $3 \%$ (Table 3 ). The mean proportion of chl $b$ containing chlorophytes and prasinophytes, however, was greater during Expt $2(26 \%)$ than Expt 1 (18\%) and this observation may reflect the increase in biomass of these organisms in response to the evolving warmer, less dense water in the upper 30 to $50 \mathrm{~m}$ (cf. Figs. 8 \& 4). It is also interesting to note that the phytoplankton was composed mainly of small cells since the collective composition of prymnesiophytes, chlorophytes, prasinophytes and cryptophytes, whose cell sizes are generally $5 \mu \mathrm{m}$ or less (Burkill et al. 1987, Verity \& Vernet 1992) was at least $75 \%$.

Other contributions to the phytoplankton biomass that must be considered are the picoprokaryotes that were enumerated by Vaulot \& Marie (1993). They identified 3 picoplankton groups, Prochlorococcus spp., Synechococcus spp. and picoeukaryotes to be present in the study area, and found that the prochlorophytes exhibited very low concentrations $\left(7.5\right.$ to $10 \times 10^{3}$ cells $\mathrm{ml}^{-1}$ ). This is in contrast to other observations in the northwestern Mediterranean (Vaulot et al. 1990) and particularly the tropical Atlantic and Pacific (Chisholm et al. 1988, Goericke \& Repeta 1993) where they are most abundant. The cell counts for Synechococcus spp. and the picoeukaryotes increased in response to the warming of the surface water and if we accept a mean value of $1.6 \times 10^{-6} \mathrm{ng} \mathrm{chl}$ a cell ${ }^{-1}$ for higher light adapted Synechococcus spp. cells (Barlow \& Alberte 1985), then we estimate from the data reported by Vaulot \& Marie (1993) that the cyanobacterial cells contributed about $2 \%$ to the total chl a in the surface layers on 5 March and about $7 \%$ on 10 March. Similarly, Mediterranean strain Prochlorococcus spp. cells contain $1.52 \times 10^{-6} \mathrm{ng}$ divinyl chl $a$ cell $^{-1}$ and $0.14 \times$ $10^{-6} \mathrm{ng}$ divinyl chl $b$ cell $^{-1}$ (Partensky et al. 1993) giving estimates of $11.4 \mathrm{ng}$ divinyl chl a $\mathrm{l}^{-1}$ and 1.05 to $1.40 \mathrm{ng}$ divinyl $\mathrm{chl} b \mathrm{l}^{-1}$. This means that the prochlorophytes contributed 1 to $2 \%$ to the total chl a (chl a+ divinyl chl $a$ ) and 0.3 to $1 \%$ to the total chl $b$ in the western Alboran Sea during March 1992.

Although most of the chl biomass was concentrated in the surface Atlantic water, we were able to collect sufficient material with the aid of the in situ pumps to measure pigments in deep water (Figs. 5 \& 6). The concentrations were extremely low compared to surface samples $\left(<10 \mathrm{ng} \mathrm{l}^{-1}\right.$ ) but the detection of chl $a_{\text {, fuco- }}$ xanthin and $19^{\prime}$-hexanoyloxyfucoxanthin indicated that intact diatom and prymnesiophyte cells and/or phytodetritus were present even at $1200 \mathrm{~m}$ (Figs. 5A \& 6C). These cells may have been transported to these depths

Table 3. The chemotaxonomic contribution (\% of chlorophyll a) of diatoms (Diat), prymnesiophytes (Prym), green algae (Green), cryptophytes (Crypto) and dinoflagellates (Dino) to the integrated phytobiomass (0 to $100 \mathrm{~m}$ ) during drifter Expt 1 (4 to $8 \mathrm{March}$ )

\begin{tabular}{|c|c|c|c|c|c|c|c|c|}
\hline & \multicolumn{4}{|c|}{ Expt 1} & \multicolumn{4}{|c|}{ Expt 2} \\
\hline & 5 March & $6 \mathrm{March}$ & 7 March & Mean & $8 \mathrm{March}$ & 9 March & 10 March & Mean \\
\hline Diat & 21.1 & 22.7 & 22.3 & 22.0 & 19.9 & 23.3 & 17.2 & 19.7 \\
\hline Prym & 42.4 & 40.2 & 34.8 & 38.9 & 35.1 & 41.3 & 34.0 & 36.2 \\
\hline Green & 16.2 & 16.2 & 20.2 & 17.7 & 29.4 & 23.1 & 24.2 & 25.8 \\
\hline Crypto & 19.1 & 15.8 & 19.9 & 18.4 & 15.6 & 14.5 & 15.2 & 15.2 \\
\hline Dino & 7.8 & 6.9 & 5.8 & 6.7 & 4.8 & 1.6 & 9.5 & 5.9 \\
\hline
\end{tabular}
and drifter Expt 2 (8 to 11 March) 
by sedimentation processes within the Alboran gyre, or by subduction from further east in the flow of deep Mediterranean water towards the Straits of Gibralter The major pigments at depth, though, were the phaeopigments (Fig. 5), comprised mostly of phaeophorbides that accounted for at least $80 \%$ of the total phaeopigment molar concentration. Phaeopigments are an important marker for zooplankton grazing activity (Welschmeyer \& Lorenzen 1985, Roy et al. 1989, Head \& Harris 1992, Head \& Horne 1993, Strom 1993) and the greater concentrations in the top $200 \mathrm{~m}$ indicated that there was grazing of the phytoplankton crop in the Atlantic water (Fig. 5). The very low phaeopigment/chl ratios in the upper $100 \mathrm{~m}$ (Fig. 5) suggested that rapid export of faecal pellets and photodegradation in the euphotic zone during the day were the primary mechanisms for pigment disappearance (Welschmeyer \& Lorenzen 1985. Barlow et al. 1993b) and higher ratios would most likely have been determined at night (see Barlow et al. 1993b). Below $300 \mathrm{~m}$, the decrease in total phaeopigment/chl a ratios from 2.0 to 2.1 to 1.1 (Fig. 5) suggested that transformation of phytodetrital material was occurring in the deeper Mediterranean water. Overall, however, the contribution of phytoplankton to water column particulate matter was relatively small since the $\mathrm{POC} / \mathrm{chl}$ a ratios ranged from 120 in surface waters to 4500 at depth (Fig. 5C).

\section{Chlorophyll budget}

The vertical fluxes of pigment biomarkers (Table 2) were low relative to the integrated standing stocks (Table 1) and we estimated that the molar proportion of each pigment removed from the water column by sedimentation was $<3 \% \mathrm{~d}^{-1}$. The proportion of total chloropigments removed daily from the upper $100 \mathrm{~m}$ was $2.9 \%$ in Expt 1 and $1.2 \%$ in Expt 2, while 0.3 to $1.7 \%$ of the accessory pigments were removed in both experiments. The proportion removed in the 100 to 200 m layer was $<1 \% \mathrm{~d}^{-1}$ for all pigments. It seems, therefore, that sedimentation accounted for only a small fraction of the transformation of chl biomass in the western Alboran Sea and these observations are comparable to the losses in chl $a$ at $80 \mathrm{~m}$ in the Arabian Sea of 0.1 to $2 \%$ as reported by Passow et al. (1993). Since the phaeopigments had the highest fluxes (Table 2), we concluded that the mode of vertical transport was mainly by faecal pellet sedimentation as indicated by Peinert et al. (1993) (see 'Results'). Similar observations were noted by Pollehne et al. (1993) in the northern Indian Ocean. Phaeopigment fluxes of 0.62 and $0.31 \mathrm{mg} \mathrm{m}^{-2} \mathrm{~d}^{-1}$ at $100 \mathrm{~m}$ were greater than the mean fluxes of $0.2 \mathrm{mg} \mathrm{m}^{-2} \mathrm{~d}^{-1}$ at $120 \mathrm{~m}$ estimated for the Central Pacific Gyres (Welschmeyer \& Loren-
Table 4. Rates of various processes within the upper $100 \mathrm{~m}$ estimated from prgment budget calculations. Estimates were made from the integrated water column inventory (Table 1 ) and fluxes (Table 2) of chlorophyll a and phaeopigments. Chlorophyll a production rates were estimated from carbon based prumary production. Rates are expressed as mg chlorophyll a equivalents $\mathrm{m}^{-2} \mathrm{~d}^{-1}$

\begin{tabular}{lcc} 
Process & Expt 1 & Expt 2 \\
\hline Chlorophyll production & 4.32 & 5.48 \\
Chlorophyll net change & 2.79 & 3.22 \\
Phaeopigment net change & -0.6 & 0.49 \\
Chlorophyll sedimentation & 0.23 & 0.14 \\
Phaeopigment sedimentation & 1.04 & 0.52 \\
\cline { 2 - 3 }
\end{tabular}

zen 1985), but the fluxes at $200 \mathrm{~m}\left(0.2 \mathrm{mg} \mathrm{m}^{-2} \mathrm{~d}^{-1}\right.$ in Expt 1) were similar to a rate of $0.23 \mathrm{mg} \mathrm{m}^{-2} \mathrm{~d}^{-1}$ (at $250 \mathrm{~m}, 51^{\circ} \mathrm{N}$ ) measured by Lorenzen et al. (1983) in the subarctic Pacific.

Besides sedimentation, other processes such as photo-oxidation, grazing, bacterial lysis and in situ degradation are active in transforming the chlorophyll biomass within the water column (Daley 1973a, b, Welschmeyer \& Lorenzen 1985, Llewellyn 1989, Head \& Horne 1993), and we have used simple budget calculations to estimate rates of some processes to account for the fate of chl $a$ in the upper $100 \mathrm{~m}$ (Table 4). Fig. 9 broadly summarizes the pathways of chlorophyll production, degradation and transformation that occur in the water column.

Processes that were measured directly included the net change with time of integrated chl $a$ and phaeopigment concentrations (Table 1) and the vertical fluxes of these pigments (Table 2). Degradation and transformation rates were not measured. Chlorophyll production was estimated from the mean of trapezoidal integrated primary production measurements in the upper $75 \mathrm{~m}$ undertaken during the cruise by Owens et al. (1993) and a carbon/chl a ratio of 50 . Primary production was

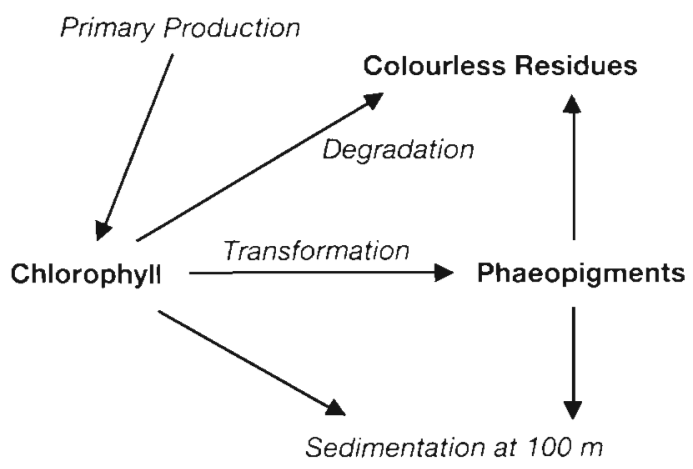

Fig. 9. Proposed scheme of chlorophyll production, degradation and transformation in the upper $100 \mathrm{~m}$ water column 
Table 5. The fate of chlorophyll a and phaeopigments in the upper $100 \mathrm{~m}$ of the western Alboran Sea during Spring 1992. The data are expressed as a percentage of chlorophyll production. The proportion of chlorophyll and phaeopigment not accounted for by accumulation or sedimentation is designated as chloropigment degraded to colourless residues

\begin{tabular}{|lrr|}
\hline & Expt 1 & Expt 2 \\
\hline Chlorophyll accumulation & $64.6 \%$ & $58.7 \%$ \\
Chlorophyll sedimentation & $5.3 \%$ & $2.6 \%$ \\
Phaeopigment accumulation & & $8.9 \%$ \\
$\begin{array}{l}\text { Phaeopigment sedimentation } \\
\text { Chloropigment degradation } \\
\text { to colourless residues }\end{array}$ & $24.1 \%$ & $9.5 \%$ \\
\hline
\end{tabular}

determined from size-fractionated ${ }^{14} \mathrm{C}$ assimilation experiments employing $24 \mathrm{~h}$ in situ incubations (Owens et al. 1993), while the carbon/chl a ratio was determined from the mean of carbon and chl a measurements on 26 various microalgal cultures grown under various irradiance levels in exponential phase ( $R$. Harris unpubl. data). Chlorophyll a production was greater in Expt 2, leading to a slightly higher net accumulation of chlorophylls and phaeopigments in this experiment (Table 4). The sedimentation of phaeopigments was twice as great in Expt 1, but the rate of chlorophyll sedimentation was very low in both experiments. To better understand the fate of these chloropigments in the water column, the rate estimates in Table 4 were expressed as a percentage of chlorophyll production (Table 5).

The data in Table 5 illustrate that 58 to $65 \%$ of the chlorophyll production in the western Alboran Sea during spring 1992 accumulated in the upper $100 \mathrm{~m}$. The mechanism responsible for this was most likely the stabilization of the water column (Fig. 4), resulting in decreased vertical mixing and a consequent reduction in vertical export, trapping the phytoplankton in the upper water column. Furthermore, the rapidly sinking particles that sediment out of the surface layers (Knauer et al. 1979, Urrere \& Knauer 1981) may contain debris from larger algal cells such as diatoms and dinoflagellates (Passow \& Peinert 1993, Passow et al. 1993, Pollehne et al. 1993), but in this investigation the phytoplankton was dominated by small cells whose contribution was at least $75 \%$ (Table 3 and discussion above). Since the sedimentation rate of small cells is low (Passow \& Peinert 1993), we suggest that the dominance of the community by prymnesiophytes, prasinophytes, chlorophytes and cryptophytes in the western Alboran Sea was a further contributory factor to the accumulation of chlorophyll biomass.

A significant fraction ( 30 to $40 \%$ ) of the chlorophyll production was degraded to colourless residues and transformed to phaeopigments, but the fate of the chlorophyll was quite different between the 2 experiments. In Expt 1, 29\% of the chlorophyll sedimented out as intact chlorophyll (5\%) or phaeopigment $(24 \%)$ at $100 \mathrm{~m}$ and only $6 \%$ was degraded to colourless residues (Table 5). In Expt 2, degradation to colourless residues was more important $(20 \%)$ than sedimentation (12\% total) and there was also some accumulation as phaeopigments $(9 \%)$. These differences suggested that mesozooplankton grazing activity to produce faecal pellets that sedimented rapidly was a more important process in Expt 1, while in Expt 2 microzooplankton grazing on small phytoplankton cells yielded products that were degraded to colourless residues within the upper water column by such processes as photo-oxidation and bacterial activity.

Acknowledgements. We thank Dr A Spitzy, chief scientist, and the officers and crew of the RV 'Valdivia' for their expert assistance during the cruise. This research was supported by the European CEC EROS 2000 programme under contract STEP-CT90-0080 (DSCN)

\section{LITERATURE CITED}

Barlow RG, Alberte RS (1985) Photosynthetic characteristics of phycoerythrin-containing marine Synechococcus spp. I. Responses to growth photon flux density. Mar Biol 86 $63-74$

Barlow RG, Mantoura RFC, Gough MA, Fileman TW (1993a) Pigment signatures of the phytoplankton composition in the northeastern Atlantic during the 1990 spring bloom Deep Sea Res II 40:459-477

Barlow RG, Mantoura RFC, Gough MA, Fileman TW (1993b) phaeopigment distribution during the 1990 spring bloom in the northeastern Atlantic. Deep Sea Res I 40:2229-2242

Bidigare RR, Marra J, Dickey TD, Iturriaga R, Baker KS, Smith RC, Pak H (1990) Evidence for phytoplankton succession and chromatic adaptation in the Sargasso Sea during spring 1985. Mar Ecol Prog Ser 60:113-122

Burkill PH, Mantoura RFC, Llewellyn CA, Owens NJP (1987) Microzooplankton grazing and selectivity of phytoplankton in coastal waters. Mar Biol 93:581-590

Chisholm SW, Olson RJ, Zettler ER, Goericke R, Waterbury JB, Welschmeyer NA (1988) A novel free-living prochlorophyte abundant in the oceanic euphotic zone. Nature 334 : $340-343$

Claustre H, Kerherve P, Marty JC, Prieur L (1994a) Phytoplankton photoadaptation related to some frontal physical processes. J mar Syst 5:251-265

Claustre H, Kerherve P, Marty JC, Prieur L, Videau C, Hecq JH (1994b) Phytoplankton dynamics associated with a geostrophic front: ecological and biogeochemical implications. J mar Res 52:711-742

Cruzado A, Martinez N (1993) Nutrient measurements during the EROS-2000 Valdivia cruise in the western Mediterranean. Water Pollut Res Rep (CEC) 30:61-66

Daley R (1973a) Experimental characterization of lacustrine chlorophyll diagenesis. I. Physiological and environmental effects. Arch Hydrobiol 72:277-304

Daley R (1973b) Experimental characterization of lacustrine chlorophyll diagenesis. II. Bacterial, viral and herbivore grazing effects. Arch Hydrobiol 72:409-439 
Everitt DA, Wright SW, Volkman JK, Thomas DP, Lindstrom EJ (1990) Phytoplankton community compositions in the western equatorial Pacific determined from chlorophyll and carotenoid pigment distributions. Deep Sea Res 37 : 975-997

Gascard JC, Richez C (1985) Water masses and circulation in the western Alboran Sea and in the Straits of Gibralter. Prog Oceanogr 15:157-216

Gieskes WWC, Kraay GW, Nontji A. Setiapermana D, Sutomo (1988) Monsoonal alteration of a mixed and a layered structure in the phytoplankton of the euphotic zone of the Banda Sea (Indonesia): a mathematical analysis of algal pigment fingerprints. Neth J Sea Res 22:123-137

Goericke R, Repeta DJ (1992) The pigments of Prochlorococcus marinus: the presence of divinyl chlorophyll a and $b$ in a marine procaryote. Limnol Oceanogr 37 : $425-433$

Goericke R, Repeta DJ (1993) Chlorophylls $a$ and $b$ and divinyl chlorophylls $a$ and $b$ in the open subtropical North Atlantic Ocean. Mar Ecol Prog Ser 101:307-313

Head EJH, Hargrave BT, Subba Rao DV (1994) Accumulation of a phaeophorbide a-like pigment in sediment traps during late stages of a spring bloom: a product of dying algae? Limnol Oceanogr 39:176-181

Head EJH, Harris LR (1992) Chlorophyll and carotenoid transformation and destruction by Calanus spp. grazing on diatoms. Mar Ecol Prog Ser 86:229-238

Head EJH, Horne EPW (1993) Pigment transformation and vertical flux in an area of convergence in the north Atlantic. Deep Sea Res II 40:329-346

Jeffrey SW, Humphrey GF (1975) New spectrophotometric equations for determining chlorophylls $a_{1}, b, c_{1}$ and $c_{2}$ in higher plants, algae and natural phytoplankton. Biochem Physiol Pflanz 167:191-194

Knauer GA, Martin JH, Bruland KW (1979) Fluxes of particulate carbon, nitrogen, and phosphorous in the upper water column of the northeast Pacific. Deep Sea Res 26:97-108

La Violette PE (1984) The advection of submesoscale thermal features in the Alboran Sea gyre. J phys Oceanogr 14: $550-565$

Llewellyn CA (1989) Chlorophyll photodegradation with the emphasis on the fate of chlorophyll in natural waters. MSc thesis, University of Bristol

Lohrenz SE, Wiesenburg DA, DePalma IP, Johnson KS, Gustafson DE (1988) Interrelationships among primary production, chlorophyll, and environmental conditions in frontal regions of the western Mediterranean Sea. Deep Sea Res 35:793-810

Lorenzen CJ, Welschmeyer NA, Copping AE (1983) Particulate organic carbon flux in the subarctic Pacific. Deep Sea Res 30:639-643

Mantoura RFC, Barlow RG, Llewellyn CA (1990) HPLC studies of summer and winter distributions of carotenoid and chlorophyll pigments in the north west Mediterranean Sea. Water Pollut Res Rep (CEC) 20:155-166

Minas HJ, Coste B, Le Corre P, Minas M, Raimbault P (1991) Biological and geochemical signatures associated with the water circulation through the Strait of Gibraltar and in the western Alboran Sea. J geophys Res 96:8755-8771

Minas HJ, Coste B, Minas M (1984) Océanographie du détroit de Gibraltar et des parages annexes. Le Courr CNRS (Centl Natl Rech Sci, Paris) 57:10-17

Ondresuk ME, Bidigare RR, Sweet ST, Defreitas DA, Brooks JM (1991) Distribution of phytoplankton pigments in the
North Pacific Ocean in relation to physical and optical variability. Deep Sea Res 38:243-266

Owens NJP, Plummer DH, Rees AP, Woodward EMS, Jones S (1993) Primary production and nitrogen assimilation in the SW Mediterranean Sea: The Valdivia 1992 cruise. Water Pollut Res Rep (CEC) 30:93-96

Packard TT, Minas HJ, Coste B, Martinez R, Bonin MC, Gostan J, Garfield P, Christensen J, Dortch Q, Minas M, Copin-Montegut G, Copin-Montegut C (1988) Formation of the Alboran oxygen minimum zone. Deep Sea Res 35: 1111-1118

Partensky F, Hoepffner N, Li WKW, Ulloa O, Vaulot D (1993) Photoacclimation of Prochlorococcus sp. (Prochlorophyta) strains isolated from the North Atlantic and the Mediteranean Sea. Plant Physiol 101:285-296

Passow U, Peinert R (1993) The role of plankton in particle flux: two case studies from the northeast Atlantic. Deep Sea Res II 40:573-585

Passow U, Peinert R, Zeitzschel B (1993) Distribution and sedimentation of organic matter during the inter-monsoon period off Oman (West Arabian Sea). Deep Sea Res II 40:833-849

Peinert RD, Fowler SW, Hamilton TF, Larosa J, Barlow RG (1993) Vertical particulate fluxes in relation to suspended particles in the western Alboran Sea. Water Pollut Res Rep (CEC) 30:195-201

Pollehne F, Klein B, Zeitschel B (1993) Low light adaptation and export production in the deep chlorophyll maximum layer in the northern Indian Ocean. Deep Sea Res II 40: $737-752$

Roy S, Harris RP, Poulet SA (1989) Inefficient feeding by Calanus helgolandicus and Temora longicornis on Coscinodiscus wailesii: quantitative estimation using chlorophyll-type pigments and effects on dissloved free amino acids. Mar Ecol Prog Ser 52:145-153

Strom SL (1993) Production of phaeopigments by marine protozoa: results of laboratory experiments analysed by HPLC. Deep Sea Res I 40:57-80

Urrere MA, Knauer GA (1981) Zooplankton fecal pellet fluxes and vertical transport of particulate organic material in the pelagic environment. J Plankton Res 3:369-387

Vaulot D, Marie D (1993) Photosynthetic picoplankton in the western Alboran Sea in March 1992. Water Pollut Res Rep (CEC) 30:67-72

Vaulot D, Partensky F, Neveux J, Mantoura RFC, Llewellyn CA (1990) Winter presence of prochlorophytes in surface waters of the northwestern Mediterranean Sea. Limnol Oceanogr 35:1156-1164

Verardo DJ, Froelich PN, McIntyre A (1990) Determination of organic carbon and nitrogen in marine sediments using the Carbo Erba NA-1500 Analyser. Deep Sea Res $37: 157-165$

Verity PG, Vernet M (1992) Microzooplankton grazing, pigments, and composition of plankton communities during late spring in two Norwegian fjords. Sarsia 77:263-274

Welschmeyer NA, Lorenzen CJ (1985) Chlorophyll budgets: Zooplankton grazing and phytoplankton growth in a temperate fjord and the Central Pacific Gyres. Limnol Oceanogr 30:1-21

Wright SW, Jeffrey SW, Mantoura RFC, Llewellyn CA, Bjornland T, Repeta D, Welschmeyer N (1991) Improved HPLC method for the analysis of chlorophylls and carotenoids from marine phytoplankton. Mar Ecol Prog Ser 77:183-196

Manuscript first received: May 26, 1994

Revised version accepted: March 27, 1995 